Article

\title{
Estimating and Decomposing Groundnut Gender Yield Gap: Evidence from Rural Farming Households in Northern Nigeria
}

\author{
Geoffrey Muricho ${ }^{1, *}$, Jourdain Lokossou ${ }^{2} \mathbb{}$, Hippolyte Affognon ${ }^{3}$, Benjamin Ahmed ${ }^{4}$, \\ Haile Desmae ${ }^{2}$, Hakeem Ajeigbe ${ }^{5}$, Michael Vabi ${ }^{5}$, Jummai Yila ${ }^{2}$, Essegbemon Akpo ${ }^{1}$ \\ and Christopher Ojiewo ${ }^{1}$ (I) \\ 1 International Crops Research Institute for the Semi-Arid Tropics (ICRISAT), Nairobi 00623, Kenya; \\ e.akpo@cgiar.org (E.A.); c.ojiewo@cgiar.org (C.O.) \\ 2 International Crops Research Institute for the Semi-Arid Tropics (ICRISAT), Bamako BP 320, Mali; \\ jlokossou@outlook.com (J.L.); h.desmae@cgiar.org (H.D.); J.O.Yila@cgiar.org (J.Y.) \\ 3 West and Central African Council for Agricultural Research and Development (CORAF), Dakar B.P.48, \\ Senegal; h.affognon@coraf.org \\ 4 Department of Agricultural Economics, Faculty of Agriculture/Institute for Agricultural Research, \\ Ahmadu Bello University, Zaria PMB 06, Nigeria; ahmedben33@gmail.com \\ 5 International Crops Research Institute for the Semi-Arid Tropics (ICRISAT), Kano PMB 3491, Nigeria; \\ H.Ajeigbe@cgiar.org (H.A.); M.Vabi@cgiar.org (M.V.) \\ * Correspondence: g.muricho@cgiar.org
}

Received: 1 September 2020; Accepted: 23 October 2020; Published: 27 October 2020

check for updates

\begin{abstract}
Poverty among smallholder farmers in sub-Saharan Africa has been associated with low agricultural productivity emanating from gender yield gaps among other factors. Using data collected from smallholder groundnut producers in Nigeria, we analyzed the gender yield gap by applying the exogenous switching regression (ESR) model and Oaxaca-Blinder (OB) decomposition framework. Results from the two complementary approaches showed a significant gender yield gap in favor of male headed households (MHHs). The main and significant source of the gap was differences in resources/endowments. We found that involving female headed households (FHHs) in prerequisite yield augmenting activities like technology validation trials, testing, and demonstrations is critical in closing the existing yield gap.
\end{abstract}

Keywords: groundnut; Nigeria; gender; yield gap; resources

\section{Introduction}

Sub-Saharan Africa (SSA) has a disproportionately higher number of poor people in the world than any other region. Available data shows that about $13 \%$ of the total world population is in SSA but the region accounts for about $56 \%$ of the poor people in the world [1]. Most of these poor people are in rural areas, most of them ( $80 \%)$ engaged in agriculture to earn their livelihoods [2]. This pervasive and persistent poverty in SSA has been associated with low agricultural productivity [3]. The region has the lowest agricultural productivity in the world, yet evidence shows that increasing farm yields is likely to reduce poverty significantly [4-7]. No other economic sector can significantly reduce poverty like the agricultural sector [8].

In many countries of SSA, low agricultural productivity is driven by the overarching challenge of gender disparity in access, control, and utilization of production resources [9-14]. Even though women contribute about $50 \%$ of agricultural labor, structural barriers limit female farmers' productivity in the African agricultural landscape [15]. Women in the SSA agricultural sector are discriminated against 
in terms of access to key factors of production like land and capital. Most times when women are allocated land for farming, it is the least fertile. This gendered disadvantage has contributed to the persistent gender productivity gap in agriculture, which stands at not less than $20 \%$ [13]. Closing this gender productivity gap is critical to increasing agricultural production, cash incomes, and poverty reduction or even eradication altogether. In fact, it has been asserted that closing the gender yield gap in SSA could increase agricultural productivity of women by between $20-30 \%[10,11,16]$, which in turn is likely to increase agricultural production in the region by between $2.5-4 \%$ and lift over 100 million people out of poverty [15]. Addressing causes of the gender productivity gap is also likely to translate into improved welfare outcomes at the household and individual level e.g., better food and nutritional outcomes because it has been shown that women spend more of their cash incomes on household food than men [17-19].

Given these compelling reasons for addressing agricultural gender productivity gaps in SSA, several studies have been conducted in the recent past [10-14,20-22]. These studies have used different datasets and methodologies in estimating and analyzing the productivity gap. In terms of data differences, there are those studies that have used cross-sectional and panel data, while within these broad data types, there are studies that have used intra-household and inter-households gender differentiated data $[23,24]$. The applicability of the results derived from these different studies that used diverse datasets and analytical methods are limited in deriving cross-cutting and comparable policy options. The underlying finding across the literature is that once differences in access and control of agricultural inputs (labor, fertilizer, seed, etc.), human capital (education, experience, etc.), and institutions (land tenure, markets, social capital, etc.) are equalized, the gender yield gap will be closed. However, the magnitude of the yield gap and its drivers are likely to be region, country, or even crop specific, thereby invalidating the one-size-fits-all recommendations or policy options. Therefore, the current study adds to this growing literature of analyzing the gender agricultural productivity gap by estimating and analyzing the groundnut gender yield gap among smallholder producers in Nigeria. The exogenous switching regression (ESR) model is adopted to estimate the yield gap. The ESR results are complemented with the Oaxaca-Blinder (OB) decomposition framework which is used to analyze the sources of the yield gap. These two approaches are complementary because the ESR estimates the gender yield gap by controlling for observed and unobserved covariates in its counterfactual framework though it does not pin-point the exact policy variables for reducing or closing the estimated yield gap. On the other hand, apart from assessing the robustness of the estimated gender yield gap derived from the ESR model, the OB framework estimates the yield gap using observed characteristics only but goes a step further to identify the specific policy options that can be used to close the gap. To the best of our knowledge, this kind of work has not been conducted in Nigeria's groundnut sub-sector.

The rest of the paper is organized as follows: - Section 2 outlines how the data used herein were collected and analyzed using the ESR and OB approaches. In Section 3, we present and discuss both summary descriptive statistics and econometric results. The counterfactual results from the ESR and OB yield gap decomposition analysis are emphasized in the discussions to highlight the level of the groundnut gender yield gap, its sources and policy options for closing this gap. The summary and conclusions of this study are given in Section 4 .

\section{Materials and Methods}

The gender productivity gap is generally analyzed from two perspectives: First, inter household analysis where sex of the household head is used as the basis of yield comparison. Secondly, the intra-household analysis where sex of the plot manager is used to compare yields. While the latter approach might have been more informative than the former, we use the former in this study due to data limitations. Having recognized the possible limitation of this study for lacking data on sex of the plot manager, it is equally important to note that sex of the household head is a good proxy of sex of the plot manager especially in a rural African setting. In fact, in their gender productivity gap 
study in Malawi, [16] found that plot managers corresponded to household heads in an overwhelming sample of households. This is particularly true in the Muslim controlled states in Nigeria, where the current study was conducted.

\subsection{Materials}

This paper is based on plot level data collected from 1311 smallholder rural farming households in five states of Nigeria (Bauchi, Jigawa, Kano, Katsina, and Kebbi). A multi-stage sampling procedure was used in selecting the surveyed households. First, the five states were purposively sampled because they were the states in which the Tropical Legumes Project (TL II and TL III refer to Phases I and II, respectively, of a Bill and Melinda Gates Foundation (BMGF)-funded project called Tropical Legumes (TL). The project aimed at development and dissemination of improved varieties of selected legume crops including groundnut. The project covered several countries in South Asia and sub-Saharan Africa including Nigeria) Phase II and Phase III activities were implemented, and promotion of improved groundnut varieties was undertaken under the two phases of the TL project since 2011. In each state, three most important local government authorities (LGAs) were purposively sampled and three villages in each of the LGAs were also purposively sampled based on the intensity of improved groundnut variety promotional activities (demonstrations, field days, trials, seed production, and upscaling). The three villages included two beneficiaries and one non-beneficiary. From each village, 10-35 groundnut farming households were randomly selected to make it up to 100 sampled households per LGA. Respondent farmers from the sampled households were interviewed by trained and experienced enumerators using a semi structured questionnaire that had been pre-tested. The collected data included household socioeconomic and demographic characteristics and groundnut production activities at plot level among other variables.

\subsection{Methods}

The traditional approach of estimating the classical production function was followed (Equation (1)):

$$
Y_{i j}=f\left(V_{i j}, X_{i}\right)
$$

where:

$Y_{i j}$ is the groundnut yield of household $i$ on plot $j$,

$V_{i}$ is the vector of plot level characteristics including inputs used by household $i$ on plot $j$,

$X_{i}$ is the vector of individual household/farmer attributes (household and community level characteristics) in household $i$.

The dependent variable $\left(Y_{i j}\right)$ in our econometric estimations is groundnut yield that is measured in $\mathrm{kg} / \mathrm{ha}$ while independent variables $\left(V_{i j}, X_{i}\right)$ are included in the models based on theory and past empirical studies $[20,24,25]$. We compare groundnut yield in this study using sex (gender) of the household head and it is used as a proxy of gender of the plot manager following [24]. The independent variables are categorized into household socioeconomic and plot-level characteristics. Household socioeconomic characteristics include household head specific attributes like age, education, marital status, participation/involvement in agricultural research activities like on-farm trials, demonstrations, and field days among other characteristics (Table 1). Additionally, included under household socioeconomic variables are distance to main market, visits by agricultural extension agents, household size (male and female members), and location fixed effects proxied by the district where the sampled households are located. On other hand, plot-level characteristics include type of groundnut variety grown on the plot (improved or local), size of the plot, time of sowing, time of harvesting, plot soil fertility, labor used on the plot, and other yield augmenting plot-level variables (Table 1). 
Table 1. Descriptive summary statistics.

\begin{tabular}{|c|c|c|c|c|c|}
\hline Variable Name & Variable Label & $\begin{array}{c}\text { All } \\
(\mathrm{N}=1651)\end{array}$ & $\begin{array}{c}\text { Male } \\
(\mathrm{N}=1518)\end{array}$ & $\begin{array}{l}\text { Female } \\
(N=133)\end{array}$ & Mean Diff \\
\hline yield & $\begin{array}{l}\text { Groundnut yield } \\
(\mathrm{kg} / \mathrm{ha})\end{array}$ & $\begin{array}{c}705.247 \\
(559.235)\end{array}$ & $\begin{array}{c}721.195 \\
(557.073)\end{array}$ & $\begin{array}{c}523.223 \\
(553.662)\end{array}$ & $197.973^{* * *}$ \\
\hline gnutvar & $\begin{array}{l}\text { Type of the groundnut variety } \\
(1=\text { Improved; } 0=\text { Local })\end{array}$ & $\begin{array}{c}0.420 \\
(0.494)\end{array}$ & $\begin{array}{c}0.408 \\
(0.492)\end{array}$ & $\begin{array}{c}0.556 \\
(0.499)\end{array}$ & $-0.149 * * *$ \\
\hline plotsize & $\begin{array}{l}\text { Plot size } \\
\text { (ha) }\end{array}$ & $\begin{array}{c}2.275 \\
(15.438)\end{array}$ & $\begin{array}{c}2.333 \\
(16.096)\end{array}$ & $\begin{array}{c}1.612 \\
(1.210)\end{array}$ & 0.721 \\
\hline sowtime & $\begin{array}{l}\text { Planted on time } \\
(1=\text { Yes; } 0=\text { No })\end{array}$ & $\begin{array}{c}0.912 \\
(0.284)\end{array}$ & $\begin{array}{c}0.920 \\
(0.271)\end{array}$ & $\begin{array}{c}0.812 \\
(0.392)\end{array}$ & $0.108^{* * *}$ \\
\hline harvtime & $\begin{array}{l}\text { Harvested on time } \\
(1=\text { Yes; } 0=\text { No })\end{array}$ & $\begin{array}{c}0.898 \\
(0.302)\end{array}$ & $\begin{array}{c}0.907 \\
(0.290)\end{array}$ & $\begin{array}{c}0.797 \\
(0.404)\end{array}$ & $0.110 * * *$ \\
\hline plotenure & $\begin{array}{c}\text { Land ownership } \\
(1=\text { Individual; } 0= \\
\text { Collective })\end{array}$ & $\begin{array}{c}0.838 \\
(0.368)\end{array}$ & $\begin{array}{c}0.854 \\
(0.353)\end{array}$ & $\begin{array}{c}0.662 \\
(0.475)\end{array}$ & $0.192^{* * *}$ \\
\hline intercrop & $\begin{array}{l}\text { Groundnut plot intercropped } \\
\qquad(1=\text { Yes; } 0=\mathrm{No})\end{array}$ & $\begin{array}{c}0.517 \\
(0.500)\end{array}$ & $\begin{array}{c}0.534 \\
(0.499)\end{array}$ & $\begin{array}{c}0.323 \\
(0.470)\end{array}$ & $0.210^{* * *}$ \\
\hline roration 2 & $\begin{array}{l}\text { Crop rotation on the plot } \\
\qquad(1=\text { Yes; } 0=\text { No })\end{array}$ & $\begin{array}{c}0.445 \\
(0.497)\end{array}$ & $\begin{array}{c}0.450 \\
(0.498)\end{array}$ & $\begin{array}{c}0.383 \\
(0.488)\end{array}$ & 0.066 \\
\hline soilfert1 & $\begin{array}{l}\text { Poor soil fertility plot } \\
\quad(1=\text { Yes; } 0=\text { No })\end{array}$ & $\begin{array}{c}0.025 \\
(0.158)\end{array}$ & $\begin{array}{c}0.026 \\
(0.160)\end{array}$ & $\begin{array}{c}0.015 \\
(0.122)\end{array}$ & 0.011 \\
\hline soilfert2 & $\begin{array}{l}\text { Fair soil fertility plot } \\
\quad(1=\text { Yes; } 0=\text { No })\end{array}$ & $\begin{array}{c}0.157 \\
(0.364)\end{array}$ & $\begin{array}{c}0.155 \\
(0.362)\end{array}$ & $\begin{array}{c}0.173 \\
(0.380)\end{array}$ & -0.017 \\
\hline soilfert3 & $\begin{array}{l}\text { Good soil fertility plot } \\
\quad(1=\text { Yes; } 0=\text { No })\end{array}$ & $\begin{array}{c}0.661 \\
(0.474)\end{array}$ & $\begin{array}{c}0.667 \\
(0.472)\end{array}$ & $\begin{array}{c}0.594 \\
(0.493)\end{array}$ & 0.073 * \\
\hline soilfert4 & $\begin{array}{l}\text { Very good soil fertility plot } \\
\quad(1=\text { Yes; } 0=\text { No })\end{array}$ & $\begin{array}{c}0.157 \\
(0.364)\end{array}$ & $\begin{array}{c}0.152 \\
(0.359)\end{array}$ & $\begin{array}{c}0.218 \\
(0.414)\end{array}$ & $-0.067 * *$ \\
\hline seedrate & $\begin{array}{l}\text { Groundnut seed rate } \\
\qquad(\mathrm{kg} / \mathrm{ha})\end{array}$ & $\begin{array}{l}33.778 \\
(73.017)\end{array}$ & $\begin{array}{l}33.436 \\
(73.979)\end{array}$ & $\begin{array}{l}37.685 \\
(61.086)\end{array}$ & -4.249 \\
\hline fertizerate & $\begin{array}{l}\text { Groundnut fertilizer rate } \\
\qquad(\mathrm{kg} / \mathrm{ha})\end{array}$ & $\begin{array}{c}177.294 \\
(1250.602)\end{array}$ & $\begin{array}{c}171.761 \\
(1197.186)\end{array}$ & $\begin{array}{c}240.450 \\
(1753.315)\end{array}$ & -68.690 \\
\hline manurate & $\begin{array}{l}\text { Groundnut manure rate } \\
\qquad(\mathrm{kg} / \mathrm{ha})\end{array}$ & $\begin{array}{c}693.834 \\
(2469.259)\end{array}$ & $\begin{array}{c}726.407 \\
(2547.946)\end{array}$ & $\begin{array}{c}322.058 \\
(1206.185)\end{array}$ & 404.349 * \\
\hline lvstckrate & $\begin{array}{l}\text { Livestock grazing rate on } \\
\text { groundnut plot } \\
\text { (\# livestock/ha) }\end{array}$ & $\begin{array}{c}6.045 \\
(23.349)\end{array}$ & $\begin{array}{c}5.838 \\
(23.474)\end{array}$ & $\begin{array}{c}8.414 \\
(21.810)\end{array}$ & -2.576 \\
\hline malelbrate & $\begin{array}{c}\text { Male labor rate on groundnut } \\
\text { plot } \\
\text { (\#male/ha) }\end{array}$ & $\begin{array}{c}9.848 \\
(47.313)\end{array}$ & $\begin{array}{c}9.853 \\
(46.874)\end{array}$ & $\begin{array}{c}9.794 \\
(52.258)\end{array}$ & 0.059 \\
\hline femalelbrate & $\begin{array}{l}\text { Female labor rate on } \\
\text { groundnut plot (\#female/ha) }\end{array}$ & $\begin{array}{c}2.589 \\
(35.032)\end{array}$ & $\begin{array}{c}2.698 \\
(36.526)\end{array}$ & $\begin{array}{l}1.345 \\
(2.469)\end{array}$ & 1.353 \\
\hline childlbrate & $\begin{array}{l}\text { Children labor rate on } \\
\text { groundnut plot } \\
\text { (\#children/ha) }\end{array}$ & $\begin{array}{c}2.274 \\
(30.912)\end{array}$ & $\begin{array}{c}2.366 \\
(32.226)\end{array}$ & $\begin{array}{l}1.218 \\
(2.820)\end{array}$ & 1.148 \\
\hline strigacontrol & $\begin{array}{l}\text { Striga control on the plot } \\
\qquad(1=\text { Yes; } 0=\text { No })\end{array}$ & $\begin{array}{c}0.121 \\
(0.326)\end{array}$ & $\begin{array}{c}0.119 \\
(0.323)\end{array}$ & $\begin{array}{c}0.143 \\
(0.351)\end{array}$ & -0.024 \\
\hline ageHH & $\begin{array}{l}\text { Age of the household head } \\
\text { (years) }\end{array}$ & $\begin{array}{c}45.752 \\
(11.907)\end{array}$ & $\begin{array}{c}46.291 \\
(11.800)\end{array}$ & $\begin{array}{c}39.609 \\
(11.430)\end{array}$ & $6.681^{* * *}$ \\
\hline yrsfschoolHH & $\begin{array}{l}\text { Household head years of } \\
\text { formal education (years) }\end{array}$ & $\begin{array}{c}3.077 \\
(6.933)\end{array}$ & $\begin{array}{c}3.194 \\
(7.115)\end{array}$ & $\begin{array}{c}1.737 \\
(4.130)\end{array}$ & $1.457^{* *}$ \\
\hline
\end{tabular}


Table 1. Cont.

\begin{tabular}{|c|c|c|c|c|c|}
\hline Variable Name & Variable Label & $\begin{array}{c}\text { All } \\
(\mathrm{N}=1651)\end{array}$ & $\begin{array}{c}\text { Male } \\
(\mathrm{N}=1518)\end{array}$ & $\begin{array}{l}\text { Female } \\
(\mathrm{N}=133)\end{array}$ & Mean Diff \\
\hline mainoccupHH1 & $\begin{array}{c}\text { Farming }(\text { crop }+ \text { livestock }) \\
\text { main occupation of } \\
\text { household head } \\
(1=\text { Yes; } 0=\mathrm{No})\end{array}$ & $\begin{array}{c}0.865 \\
(0.342)\end{array}$ & $\begin{array}{c}0.868 \\
(0.339)\end{array}$ & $\begin{array}{c}0.835 \\
(0.373)\end{array}$ & 0.033 \\
\hline mstatusHH2 & $\begin{array}{c}\text { Household head } \\
\text { marital status } \\
(1=\text { Married; } 0=\text { Otherwise })\end{array}$ & $\begin{array}{c}0.965 \\
(0.184)\end{array}$ & $\begin{array}{c}0.980 \\
(0.139)\end{array}$ & $\begin{array}{c}0.789 \\
(0.409)\end{array}$ & $0.191^{* * *}$ \\
\hline experience & $\begin{array}{l}\text { Household head } \\
\text { farming experience } \\
\text { (years) }\end{array}$ & $\begin{array}{c}22.471 \\
(12.954)\end{array}$ & $\begin{array}{c}23.037 \\
(12.945)\end{array}$ & $\begin{array}{c}16.008 \\
(11.225)\end{array}$ & $7.029^{* * *}$ \\
\hline frmlabourHH1 & $\begin{array}{l}\text { Household head full time } \\
\text { labor participation } \\
(1=\text { Yes; } 0=\text { No })\end{array}$ & $\begin{array}{c}0.803 \\
(0.398)\end{array}$ & $\begin{array}{c}0.813 \\
(0.390)\end{array}$ & $\begin{array}{c}0.684 \\
(0.467)\end{array}$ & $0.129^{* * *}$ \\
\hline involved & $\begin{array}{l}\text { Household head involved in } \\
\text { field trials/ } \\
\text { tests/demonstrations } \\
(1=\text { Yes; } 0=\mathrm{No})\end{array}$ & $\begin{array}{c}0.364 \\
(0.481)\end{array}$ & $\begin{array}{c}0.354 \\
(0.478)\end{array}$ & $\begin{array}{c}0.481 \\
(0.502)\end{array}$ & $-0.127^{* * *}$ \\
\hline hvisite & $\begin{array}{l}\text { Number of visits by } \\
\text { agricultural extension staff }\end{array}$ & $\begin{array}{c}4.236 \\
(7.727)\end{array}$ & $\begin{array}{c}4.312 \\
(7.605)\end{array}$ & $\begin{array}{l}3.376 \\
(8.994)\end{array}$ & 0.936 \\
\hline tmale & $\begin{array}{l}\text { Total male household } \\
\text { members }\end{array}$ & $\begin{array}{l}5.435 \\
(4.483)\end{array}$ & $\begin{array}{l}5.568 \\
(4.577)\end{array}$ & $\begin{array}{c}3.925 \\
(2.827)\end{array}$ & $1.643^{* * *}$ \\
\hline tfemale & $\begin{array}{l}\text { Total female household } \\
\text { members }\end{array}$ & $\begin{array}{c}4.420 \\
(4.689)\end{array}$ & $\begin{array}{c}4.548 \\
(4.793)\end{array}$ & $\begin{array}{c}2.962 \\
(2.906)\end{array}$ & $1.586^{* * *}$ \\
\hline engtrain & $\begin{array}{l}\text { At least household members } \\
\text { engaged in } \\
\text { training/technology } \\
(1=\text { Yes; } 0=\mathrm{No})\end{array}$ & $\begin{array}{c}0.207 \\
(0.405)\end{array}$ & $\begin{array}{c}0.196 \\
(0.397)\end{array}$ & $\begin{array}{c}0.331 \\
(0.472)\end{array}$ & $-0.135^{* * *}$ \\
\hline nplots & Number of cultivated plots & $\begin{array}{l}2.900 \\
(2.938)\end{array}$ & $\begin{array}{c}2.999 \\
(3.018)\end{array}$ & $\begin{array}{c}1.774 \\
(1.357)\end{array}$ & $1.224^{* * *}$ \\
\hline jigawa & Jigawa State $(1=$ Yes; $0=$ No $)$ & $\begin{array}{c}0.242 \\
(0.428) \\
\end{array}$ & $\begin{array}{c}0.227 \\
(0.419)\end{array}$ & $\begin{array}{c}0.406 \\
(0.493)\end{array}$ & $-0.179 * * *$ \\
\hline kano & Kano State $(1=$ Yes; $0=$ No $)$ & $\begin{array}{c}0.182 \\
(0.386)\end{array}$ & $\begin{array}{c}0.195 \\
(0.396)\end{array}$ & $\begin{array}{c}0.038 \\
(0.191)\end{array}$ & $0.157^{* * *}$ \\
\hline katsina & Katsina State $(1=$ Yes; $0=$ No $)$ & $\begin{array}{c}0.186 \\
(0.389)\end{array}$ & $\begin{array}{c}0.188 \\
(0.391)\end{array}$ & $\begin{array}{c}0.165 \\
(0.373)\end{array}$ & 0.022 \\
\hline kebbi & Kebbi State $(1=$ Yes; 0 = No) & $\begin{array}{c}0.196 \\
(0.397) \\
\end{array}$ & $\begin{array}{c}0.207 \\
(0.405) \\
\end{array}$ & $\begin{array}{c}0.075 \\
(0.265) \\
\end{array}$ & $0.132 * * *$ \\
\hline bauchi & Bauchi State $(1=$ Yes; $0=$ No $)$ & $\begin{array}{c}0.194 \\
(0.395)\end{array}$ & $\begin{array}{c}0.183 \\
(0.387)\end{array}$ & $\begin{array}{c}0.316 \\
(0.467)\end{array}$ & $-0.133^{* * *}$ \\
\hline
\end{tabular}

${ }^{* * *} p<0.01,{ }^{* *} p<0.05,{ }^{*} p<0.1$; values in parenthesis show standard deviations.

Initial testing of the impact of the sex of the household head on groundnut yield was conducted using the traditional ordinary least squares (OLS) regression model of including the sex dummy variable as one of the explanatory variables in the yield model. In this initial approach, the sign and the magnitude of the coefficient of the gender variable (sex of the household head) were used to interpret the impact of this gender on the outcome variable (groundnut yield). However, the assumption in this approach is that the study units (groundnut plots) are the same in all aspects except that they are different in terms of the gender variable. This assumption is too restrictive and seldom holds because groundnut plots from female headed households (FHHs) could be systematically different from those in male headed households (MHHs). To circumvent this problem, the exogenous switching regression (ESR) model that relaxes this strong assumption was used to allow the gender variable to interact with other observed and unobserved covariates in determining the outcome of interest 
(groundnut yield). Therefore, OLS was used as a diagnostic model to benchmark the gender yield gap analysis in this study. The ESR was adopted because the sex of the household head is exogenous in nature [26]. The ESR results were checked for robustness using the propensity score matching (PSM) method and complemented using the Oaxaca-Blinder $(\mathrm{OB})$ decomposition framework that allows the estimated yield gap to be decomposed into its different components. The OB results can assist to derive specific policy intervention options that are necessary for closing the existing gender yield gap among smallholder groundnut farmers in northern Nigeria.

\subsubsection{The Exogenous Switching Regression}

The traditional approach of assessing the impact of gender on yield is to include a sex dummy variable as one of the explanatory variables in the yield outcome model. In this approach, the coefficient of the sex dummy variable determines the sign and the magnitude of the gender impact. However, such approach has strong assumption that the male and female sub-samples resemble in all aspects except the sex of the household head-an assumption that seldom holds in the real-world setting. Principally, this means that the two outcome equations for the two gender regimes (female and male) have same coefficients/returns on the included explanatory variables and the only difference is their intercepts (they are parallel to each other with different intercepts i.e., same slope). Therefore, sex of the household head is simply an intercept shifter with no impact on the slope (coefficients of the included explanatory variables). The yield function of the two gender regimes is estimated separately alongside the pooled function and test this same slope assumption using the Chow test. From the Chow test, the null hypothesis of equal slope or parallel shift from male to female-headed households was rejected $($ F-statistic $=2.105 ; p$-value $=0.000)$, giving a strong indication that gender-specific coefficient estimates are more appropriate. Therefore, the impact of sex of the household head on groundnut yield gap was estimated using the exogenous switching regression (ESR) model from which a counterfactual framework was built to disentangle the impact of sex of the household head on the yield gap. In the ESR framework, two outcome models were estimated-one model for each of the gender regimes as follows:

$$
\begin{aligned}
& \text { Regime 1: } Y_{1}=X_{1} \beta_{1}+\epsilon_{1}, \\
& \text { Regime 2: } Y_{0}=X_{0} \beta_{0}+\epsilon_{0},
\end{aligned}
$$

where:

$Y_{\tau}$ are the outcome variables for male and female-headed households (groundnut yield),

$X_{\tau}$ are the observed plot and household characteristics that determine groundnut yield,

$\beta_{\tau}$ are the model parameters to be estimated,

$\epsilon_{\tau}$ are the model error terms normally distributed with constant variance and zero means,

$\tau$ is the gender identifier $(1=\mathrm{MHH} ; 0=\mathrm{FHH})$.

Deriving expected values from Equations (2) and (3) above and comparing them directly will not tell much on the actual impact of household head sex on groundnut yield gap. This is because the direct comparison of the two expected values from these two models assumes that MHHs and FHHs are, on average, similar in all aspects including amount of resources they have and returns to those resources, but only differ in the sense that one group is male-headed (MHHs) and the other is female-headed (FHHs). Such assumption is unlikely to be true because the data used in this paper is non-experimental [27] and also, Chow test results suggest that the two groups of households do not have same returns (coefficients) to their resources. Therefore, counterfactual yields of MHHs and FHHs were obtained from Equations (2) and (3), respectively following [28,29]. To build the counterfactual framework for MHHs, the expected yield of MHHs had they been headed by females was estimated. Analogously, the counterfactual for FHHs is their groundnut yield had they been headed by males. The actual and their respective counterfactual estimations can be represented using the following conditional expectations:

$$
E\left(Y_{1} / \tau=1\right)=X_{1} \beta_{1}
$$




$$
\begin{aligned}
& E\left(Y_{0} / \tau=0\right)=X_{0} \beta_{0}, \\
& E\left(Y_{0} / \tau=1\right)=X_{1} \beta_{0}, \\
& E\left(Y_{1} / \tau=0\right)=X_{0} \beta_{1} .
\end{aligned}
$$

Equations (4) and (5) are the observed actual groundnut yields form MHHs and FHHs, respectively. Following [26,30], the counterfactual yield of MHHs i.e., groundnut yield of MHHs had they been headed by females is represented by Equation (6) while the counterfactual yield of FHHs is given by Equation (7). The final interpretation of the expected actual and counterfactual yields is summarized

\begin{tabular}{|c|c|c|c|}
\hline Gender of the Household Head & MHH Characteristics & FHH Characteristics & Gender Effect \\
\hline \multirow{2}{*}{$\mathrm{MHH}$} & {$[\mathrm{A}]$} & [D] & \multirow{2}{*}{$\begin{array}{c}{[\mathbf{F}]=[\mathbf{A}]-[\mathrm{D}]} \\
X_{1} \beta_{1}-X_{0} \beta_{1} \\
=\boldsymbol{\beta}_{\mathbf{1}}\left(\boldsymbol{X}_{\mathbf{1}}-\boldsymbol{X}_{\mathbf{0}}\right)\end{array}$} \\
\hline & $E\left(Y_{1} / i=1\right)=X_{1} \beta_{1}$ & $E\left(Y_{0} / i=1\right)=X_{0} \beta_{1}$ & \\
\hline \multirow{2}{*}{ FHH } & {$[\mathrm{E}]$} & [B] & \multirow{2}{*}{$\begin{array}{c}{[\mathrm{G}]=[\mathrm{E}]-[\mathrm{B}]} \\
X_{1} \beta_{0}-X_{0} \beta_{0} \\
=\boldsymbol{\beta}_{\mathbf{0}}\left(X_{\mathbf{1}}-X_{\mathbf{0}}\right) \\
\end{array}$} \\
\hline & $E\left(Y_{1} / i=0\right)=X_{1} \beta_{0}$ & $E\left(Y_{0} / i=0\right)=X_{0} \beta_{0}$ & \\
\hline \multirow{2}{*}{ Heterogeneity effect } & {$[\mathrm{H}]=[\mathrm{A}]-[\mathrm{E}]$} & {$[\mathrm{I}]=[\mathrm{D}]-[\mathrm{B}]$} & {$[C]=[A]-[B]$} \\
\hline & $\begin{aligned} & X_{1} \beta_{1}-X_{1} \beta_{0} \\
= & \boldsymbol{X}_{\mathbf{1}}\left(\boldsymbol{\beta}_{\mathbf{1}}-\boldsymbol{\beta}_{\mathbf{0}}\right)\end{aligned}$ & $\begin{array}{c}X_{0} \beta_{1}-X_{0} \beta_{0} \\
=\boldsymbol{X}_{\mathbf{0}}\left(\boldsymbol{\beta}_{\mathbf{1}}-\boldsymbol{\beta}_{\mathbf{0}}\right)\end{array}$ & $X_{1} \beta_{1}-X_{0} \beta_{0}$ \\
\hline
\end{tabular}
in Table 2.

Table 2. Expected actual and counterfactual gendered groundnut yield framework.

Factorizing the entries in cell $\mathrm{F}$ and cell $\mathrm{G}$ gives $\beta_{1}\left(X_{1}-X_{0}\right)$ and $\beta_{0}\left(X_{1}-X_{0}\right)$, respectively. Therefore, cells $[F]$ and $[G]$ shows the effect of changing the resources/endowments $\left(X_{\tau}\right)$ held while cells $[\mathrm{H}]$ and $[\mathrm{I}]$ shows the effect of changing the returns/efficiency/coefficients $\left(\beta_{\tau}\right)$ of the resources $\left(X_{\tau}\right)$ on the outcome variable $\left(Y_{\tau}\right)$. Cells $[\mathrm{F}]$ and $[\mathrm{G}]$ are what other impact assessment literature refer to as the average treatment effect on the treated (ATT) and the average treatment effect on the untreated (ATU), respectively [26,31]. From these two cells in Table 2, it means that even if MHHs and FHHs were to have the same amounts of resources, their yields could be different due to differences in their returns/coefficients/efficiencies in their resources. Similarly, cells [H] and [I] can also be simplified to $X_{1}\left(\beta_{1}-\beta_{0}\right)$ and $X_{0}\left(\beta_{1}-\beta_{0}\right)$, respectively. This implies that even if MHHs and FHHs were to have same returns/efficiency/coefficients $\left(\beta_{\tau}\right)$, their yields might not be the same due to their differences in the amounts of resources that they have $\left(X_{\tau}\right)$. This yield gap due to differences in amounts of resources/endowments is what other impact assessment literature calls the heterogeneity effect $[26,30,32]$ or endowment effect in wage decomposition literature [33]. Finally, because the dependent variable (groundnut yield) is a continuous variable, $\beta_{\tau}$ was estimated using the OLS procedure. Finally, we check the robustness of results from this ESR model using the PSM method.

\subsubsection{The Oaxaca-Blinder (OB) Decomposition}

The yield difference between MHHs and FHHs was re-estimated using the OB decomposition framework. This method is based on the original works of $[33,34]$ that developed and applied the framework in labor economics. However, in the recent past, this method has gained prominence in the field of agricultural economics. In this approach, the variable that is used for decomposition is sex of the household head $(\tau)$, which is measured on a binary scale $(1=$ MHHs and $0=$ FHHs). The outcome variable is the yield $\left(Y_{\tau}\right)$, which is measured on a continuous scale in terms of $\mathrm{kg} / \mathrm{ha}$. This means that the yield of MHHs could be represented as $Y_{1}$ and the yield of FHHs as $Y_{0}$. Therefore, the question is how much is the yield gap between MHHs and FHHs and what are the sources of this gap? The yield gap can be represented mathematically as the following mean outcome difference:

$$
\varphi=E\left(Y_{1}\right)-E\left(Y_{0}\right)
$$


The outcome model can be modeled as:

$$
Y_{\tau}=X_{\tau}^{\prime} \beta_{\tau}+\epsilon_{\tau}, \quad E\left(\epsilon_{\tau}=0 \quad \tau \in(1,0),\right.
$$

where:

$Y_{\tau}$ is groundnut yield in regime $\tau$,

$X_{\tau}^{\prime}$ are observed household and plot-level characteristics,

$\beta_{\tau}$ are the parameters to be estimated,

$\epsilon_{\tau}$ is the error term that is normally distributed with zero mean and constant variance.

Therefore, Equation (10) is derived by substituting Equation (9) into Equation (8) as follows:

$$
\varphi=E\left(Y_{1}\right)-E\left(Y_{0}\right)=E\left(X_{1}^{\prime}\right) \beta_{1}-E\left(X_{0}^{\prime}\right) \beta_{0} .
$$

To compute the difference in the outcome variable $(\varphi)$ that is due to differences in the amounts of observed variables between the two groups of the gender (MHHs and FHHs), Equation (10) can be rearranged following [35] to give a three-fold decomposition framework as follows:

$$
\varphi=\left\{E\left(X_{1}\right)-E\left(X_{0}\right)\right\}^{\prime} \beta_{0}+E\left(X_{0}\right)^{\prime}\left(\beta_{1}-\beta_{0}\right)+\left\{E\left(X_{1}\right)-E\left(X_{0}\right)\right\}^{\prime}\left(\beta_{1}-\beta_{0}\right) .
$$

Equation (11), the aggregate decomposition [16], is a three-fold decomposition framework because it decomposes the mean difference in the outcome variable $\varphi$ (groundnut yield) into three components i.e., one component emanating from differences in the amounts of observed resources/endowments controlled for the outcome model (the $X_{\tau}$ ), secondly, differences in outcome variable as a result of differences between the two gender regimes' returns/coefficients in use of those resources i.e., the $\beta_{i}$ and, thirdly, the differences in the outcome variable that emanate from differences between MHHs' and FHHs' interaction term of amounts of resources and returns to resources $\left(X_{i} \beta_{i}\right)$. Therefore, Equation (11) can be represented simply as:

$$
\varphi=E+C+I,
$$

where:

$E$ (resource amount or endowment effect) $=\left\{E\left(X_{1}\right)-E\left(X_{0}\right)\right\}^{\prime} \beta_{0}$,

$C$ (returns or efficiency or coefficient effect $)=E\left(X_{0}\right)^{\prime}\left(\beta_{1}-\beta_{0}\right)$,

$I$ (interaction term) $=\left\{E\left(X_{1}\right)-E\left(X_{0}\right)\right\}^{\prime}\left(\beta_{1}-\beta_{0}\right)$.

Equation (11) can be formulated from the standpoint of the assumed disadvantaged group or from the advantaged group, in our case FHHs or MHHs, respectively. In this paper, and following the common practice in empirical impact assessment studies, Equation (11) has been constructed from the disadvantaged point of view i.e., the gender group differences in endowment/resources (observed characteristics) are weighted by the coefficients of the disadvantaged group (FHHs) to determine the differences in the outcome variable stemming from differences in amounts of resources/endowments between the advantaged group (MHHs) and disadvantaged group (FHHs). In other words, the endowment/resources effect measures the expected change in FHHs' yield if FHHs had the same level of resources/endowments as those that MHHs are holding currently. The vice versa is also true if Equation (11) was to be viewed from the advantaged (MHHs) point of view. A similar interpretation can also follow the returns/coefficient component $(C)$. In this regard, $C$ measures the difference in the outcome variable (groundnut yield) if disadvantaged group's (FHHs') returns/efficiency/coefficient on their resources was the same as the coefficients/returns/efficiency of the advantaged group's (MHHs'). Therefore, it follows then that Equation (11) can be expressed from the viewpoint of the advantaged group (MHHs) as follows:

$$
\theta=\left\{E\left(X_{1}\right)-E\left(X_{0}\right)\right\}^{\prime} \beta_{1}+E\left(X_{1}\right)^{\prime}\left(\beta_{1}-\beta_{0}\right)+\left\{E\left(X_{1}\right)-E\left(X_{0}\right)\right\}^{\prime}\left(\beta_{1}-\beta_{0}\right) .
$$


Equation (5) was therefore implemented using the OB framework following [35] and it was used to conduct detailed decomposition of the yield gap. Detailed decomposition involves subdividing the contribution of all the three decomposition dimensions into respective contribution of each of the controlled factors in the outcome model. It is from this detailed decomposition that specific policy option variables for closing the yield gap can be identified-what ESR is unable to do.

\section{Results and Discussions}

\subsection{Descriptive Summary Statistics}

The summary descriptive statistics of key variables used in the analysis are categorized into two main groups: -FHHs and MHHs. The significance tests of the mean difference of each variable across the two categories are presented in Table 1. First, the sample consisted of 1311 farming households cultivating a total of 1651 groundnut plots. Therefore, some households cultivate more than one groundnut plot. Out of the 1311 households that were sampled, about $8 \%$ are FHHs and equally $8 \%$ of the cultivated plots are from FHHs. The low percentage of FHHs in the sample could be due to the influence of the Islamic region in the five northern states of Nigeria where data was collected (Bauchi, Jigawa, Kano, Katsina, and Kebbi). While [36] reported 8\% FHHs in states of northwestern Nigeria, the World Bank also reports comparably small proportion of households headed by females in Nigeria in 2015 (less than 15\% nationally). Therefore, it is difficult to get a reasonably higher proportion of FHHs especially in a Muslim dominated region where the survey was conducted-more so if the sampling of respondent households was random as it was done herein.

The dependent variable for the econometric estimations was the average groundnut yield in each of the cultivated plots. The average groundnut yield was about $705 \mathrm{~kg} / \mathrm{ha}$ and MHHs have a significantly higher yield (721 kg/ha) compared to FHHs (523 kg/ha). This difference in the mean groundnut yield (198 kg/ha) between MHHs and FHHs is significant at $p<1 \%$ (Table 1) and this is consistent with previous empirical findings that have consistently found higher agricultural productivity among MHHs compared to FHHs [21,24]. The subsequent questions from this mean yield statistic were: (i) is this significant difference purely due to sex of the household (MHHs and FHHs) per se or due to other confounding factors interacting with sex of the household head? (ii) if groundnut production resources/endowments were swapped across the two categories of households, will there be a significant gender yield gap and what if returns/coefficients were swapped too? (iii) if indeed there exists a significant gender yield gap, what policy options are there to close this gap with the ultimate aim of increasing groundnut production in the northern states of Nigeria where groundnut is mostly produced? These are the fundamental questions that this paper sets out to address using econometric modeling.

Besides yield, a significant difference between FHHs and MHHs in adoption of improved groundnut varieties and other several variables was observed (Table 1). Theoretical and past empirical studies have demonstrated that plots with improved varieties usually return higher yields than otherwise. However, from the summary descriptive statistics, about $42 \%$ of the plots cultivated by the sampled farmers were under improved varieties and a significantly higher proportion of groundnut plots among the FHHs were under the improved varieties (56\%) compared to those cultivated by MHHs (41\%). This statistic is unexpected because improved varieties are assumed to be higher yielding than local varieties and given that a significantly higher proportion of FHHs have adopted improved varieties compared to MHHs, then it should logically follow that FHHs have a significantly higher yield than MHHs. This shows that FHHs have lower returns (yield) on improved groundnut varieties compared to MHHs. The reason for higher cultivation of improved varieties by FHHs may be as a direct effect of the TL project whose implementation ensured high percentage of female farmers participation. The implication of this finding could be that, just access to improved varieties alone might not guarantee higher yields-a minimum set of accompanying crop management practices are needed to enhance yield of improved groundnut varieties (timely planting, soil fertility, etc.). For example, a 
significant difference in timing for planting and harvesting of groundnut was observed. Groundnut is very susceptible to poor germination and sprouting if planted and harvested, respectively, at the wrong time, thus reducing yield [37]. A significantly higher proportion of plots from MHHs were planted and harvested on time compared to plots from FHHs (Table 1). Therefore, further investigation of the adoption and productivity gap between improved and local varieties is needed to shed more light on this unexpected finding.

\subsection{Econometric Results}

\subsubsection{OLS Regression Model of Groundnut Yield}

The traditional OLS regression model results (where sex of the household head is included as one of the explanatory variables), show that there is a significant gender yield gap in favor of MHHs (Appendix A Table A1, Model 1). Since the dependent variable was transformed into its natural log form, the results in Model 1 of Appendix A Table A1 show that MHHs have a significant yield advantage of about $31 \%$ over FHHs. This finding is consistent with past empirical studies that have shown a significantly higher agricultural productivity among MHHs compared to their female counterparts $[13,16,21,22,24]$. However, it is not clear if this significant yield gap is due to sex of the household head per se or other confounding factors affecting household headship. Therefore, further analysis is needed to disentangle the effect of household headship on the yield gap and to formulate policy options that can close this gap for increased groundnut output. Using this traditional approach of analyzing gender yield gap, other variables alongside sex of the household head were found to have significant effect in explaining the groundnut yield among sampled households (Appendix A Table A1, Model 1). These include adoption of improved groundnut varieties, increased seed rate, rotating groundnut with cereals on the plot, among many other that were positively and significantly correlated with groundnut yield. Other variables like plot size and use of manure on the plot (an indication of probably poor soil fertility) were negatively and significantly correlated with groundnut yield (Appendix A Table A1). Since the objective of this study was not to analyze determinants of groundnut yield per se, this paper does not delve into discussing the results presented in Appendix A Table A1.

\subsubsection{Exogenous Switching Regression (ESR)}

From the ESR model, the counterfactual framework following [29] was built to disentangle the effect of sex of the household head on groundnut yield stemming from observed and unobserved heterogeneities of the two groups of households (MHHs and FHHs). From Table 3, the predicted natural log of observed groundnut yield from MHHs is in cell [A] while that of FHHs is in cell [B]. The counterfactual results for MHHs and FHHs are in cell [D] and cell [E], respectively. The results from these gender effects show that groundnut plots in MHHs have a significantly higher observed yield compared to those from FHHs (cell [C]). This finding agrees with previous empirical findings summarized by [24] showing that FHHs' plots are significantly less productive compared to plots cultivated in MHHs. If that is true in our study, then the question is: -Could plots from MHHs have completely lost their yield advantage had they been from FHHs, holding all else constant? Conversely, would plots from FHHs close the observed yield gap had they been from MHHs, ceteris paribus? These are the questions that we address using the counterfactual results built from the estimated ESR model. 
Table 3. Effect of sex of the household head on groundnut yield.

\begin{tabular}{cccc}
\hline \multirow{2}{*}{ Sex of the Household Head } & \multicolumn{3}{c}{ Characteristics of the Household Head } \\
\cline { 2 - 4 } & MHHs & FHHs & Endowment Effect \\
\hline \multirow{2}{*}{ MHHs $(\mathrm{N}=1518)$} & {$[\mathrm{A}]$} & {$[\mathrm{D}]$} & {$[\mathrm{F}]=[\mathrm{A}]-[\mathrm{D}]$} \\
& 6.240 & 5.969 & $0.271^{* * *}$ \\
& $(0.012)$ & $(0.063)$ & $(0.064)$ \\
\hline \multirow{2}{*}{ FHHs $(\mathrm{N}=133)$} & {$[\mathrm{E}]$} & {$[\mathrm{B}]$} & {$[\mathrm{G}]=[\mathrm{E}]-[\mathrm{B}]$} \\
& 5.988 & 5.676 & $0.312^{* * *}$ \\
& $(0.040)$ & $(0.073)$ & $(0.083)$ \\
\hline \multirow{2}{*}{ Returns Effect } & {$[\mathrm{H}]=[\mathrm{A}]-[\mathrm{E}]$} & {$[\mathrm{I}]=[\mathrm{D}]-[\mathrm{B}]$} & {$[\mathrm{C}]=[\mathrm{A}]-[\mathrm{B}]$} \\
& $0.252^{* * *}$ & 0.293 & $0.564 * * *$ \\
& $(0.043)$ & $(0.214)$ & $(0.046)$ \\
\hline
\end{tabular}

${ }^{* * *} p<0.01$; values in parenthesis show standard errors.

Following recent empirical studies in agricultural economics that applied ESR framework $[12,13,38,39]$, the observed groundnut gender yield gap (cell [C]) is attributed to the (dis)advantages of (fe)male-headed households driven by either differences in resource/endowment amount and/or returns/coefficient effects of the advantaged gender group (MHHs) vis-a-viz the disadvantaged group (FHHs). From the counterfactual results presented in Table 3, it was observed that giving MHHs the same amount of resources/endowment like FHHs will reduce MHHs' groundnut yield significantly (cell $[\mathrm{F}]$ ). The consistency of this finding (cell $[\mathrm{F}]$ ) was confirmed from the PSM results that were generated as a robustness check (Appendix A Table A1 Model 2; Appendix A Table A2). Comparing the new yield of MHHs (cell [D]) after equalizing the amount of resources/endowments with that of FHHs (cell [B]) shows that the difference in groundnut yield between MHHs and FHHs (cell [I]) is not statistically significant. This implies that given the same amount of resources/endowments like the ones that FHHs are holding, then MHHs' groundnut yield will not be statistically different from the currently observed yield of FHHs i.e., the returns/coefficient effect is not significant. This coefficient/returns effect result support past empirical studies that have demonstrated that female farmers are as efficient as male farmers and the only difference between these two categories of farmers is the amount of resources/endowments that each hold $[7,15]$ — with most studies showing that male farmers hold more resources/endowments than their female counterparts [23,40,41]. It should be noted that no policy option that intends to increase groundnut production in Nigeria will target reducing the amount of resources held by MHHs because such a move could reduce aggregate amount of groundnut produced in the country.

On the other hand, the policy focus should be on how to uplift the productivity of FHHs so that the current yield gap can be reduced, or ultimately, be closed altogether. When FHHs are hypothetically given the same amount of resources/endowments like those currently held by MHHs, then the former's groundnut yield increases significantly (cell [G]). This new yield of FHHs after equalizing their resources/endowments with those held by MHHs, does not close the observed yield gap completely because observed yield of MHHs (cell [A]) is still significantly higher than the new yield of FHHs (cell [E]) i.e., cell [H] (Table 3). This finding implies that if FHHs' endowments/resources were the same as the current endowments/coefficients of MHHs, then the yield of the former will increase significantly though it will not be able to close the observed yield gap. Therefore, to increase women productivity and groundnut production in Nigeria, there is need to significantly reduce or close altogether this observed gender yield gap ([C]). The counterfactual results from the exogenous switching regression analysis show that the gender yield gap can be closed by addressing both the resource/endowment and returns/coefficients of FHHs. Unfortunately, this is as much that the exogenous switching regression analysis can tell about the gender yield gap. However, for the gap to be closed, there is need for specific policy options on how gendered factors such as low endowments/resources and returns/coefficient can be raised or improved to address low yield among FHHs in northern Nigeria. To identify the specific 
policy options needed for closing this gender yield gap, Oaxaca-Blinder $(\mathrm{OB})$ decomposition analysis was conducted.

\subsubsection{Oaxaca-Blinder (OB) Decomposition Analysis}

The OB framework generates more specific insights on relevant target variables for closing this groundnut gender yield gap. The dependent variable (natural log of groundnut yield) was regressed on household/community and plot specific characteristics following [16] (Appendix A Table A3). The OB analysis showed a significant gender yield gap of about $56 \%$ in favor of MHHs (Table 4 ). The main source of the gap after decomposing it was the resources/endowments which accounted for about $46 \%$ of the yield gap ( 26 percentage points of the $56 \%$ gender yield gap). The resource/endowment effect is negatively related to the gender yield gap i.e., increasing the endowment/resources held by the FHHs is likely to significantly reduce the observed groundnut gender yield gap. On the other hand, the coefficient and interaction terms are not significant sources of the yield gap though they collectively account for almost $54 \%$ of the gap. These OB results are consistent with the ESR results. Furthermore, the finding that the only significant source of the gender yield gap is resources/endowments and not returns/coefficients of the held resources confirms previous empirical works that have demonstrated that female farmers are as efficient as their male counterparts. The only thing that undermines female farmers' productivity compared to male farmers is the amount of resources female farmers have access to and control $[10,40]$.

Table 4. The gender yield gap decomposition.

\begin{tabular}{|c|c|}
\hline Predicted Yield Differential (Log of kg/ha) & Results \\
\hline FHHs & $\begin{array}{c}5.679 * * * \\
(0.112)\end{array}$ \\
\hline MHHs & $\begin{array}{c}6.244^{* * *} \\
(0.024)\end{array}$ \\
\hline Difference (proportion) & $\begin{array}{c}-0.565^{* * *} \\
(0.114)\end{array}$ \\
\hline \multicolumn{2}{|l|}{ Decomposition share } \\
\hline Endowments & $\begin{array}{c}-0.258 * * * \\
(0.059)\end{array}$ \\
\hline Coefficients & $\begin{array}{l}-0.270 \\
(0.263)\end{array}$ \\
\hline Interaction term & $\begin{array}{l}-0.037 \\
(0.256)\end{array}$ \\
\hline \multicolumn{2}{|l|}{ Decomposition share (percent) } \\
\hline Endowments & 45.627 \\
\hline Coefficients & 47.739 \\
\hline Interaction term & 6.634 \\
\hline
\end{tabular}

Further, specific policy variables needed to close the groundnut gender yield gap in Nigeria were analyzed by targeting the significant source of the yield gap i.e., the endowments/resources (Table 4). From the results presented in Table 5, six variables were identified that were significant in contributing to the endowments/resources effect on the gender yield gap. Adoption of improved groundnut varieties is found to increase the resource/endowment effect of widening the gender yield gap, that is, adopting improved groundnut varieties among smallholder groundnut producers in Nigeria is likely to increase the gender yield gap. This finding could imply that the gender yield gap is more pronounced among improved compared to local groundnut varieties i.e., MHHs have a significantly 
higher yield of improved varieties than FHHs. Therefore, it implies that for the yield gap to be narrowed down (closed at the best), policy options to increase the productivity of improved groundnut varieties among FHHs are needed. Reasons behind the low yield of improved groundnut varieties among FHHs compared to MHHs are not clear and could be the subject of further research. We also find that plot tenure (individually owned), household involvement in groundnut scaling activities like field trials/tests/demonstrations/seed fairs etc., age of the household head and total number of female household members in a household are reducing in their contribution to endowment/resources effect in the overall yield gap (Table 5). This means that policy options that can make FHHs own and operate their own groundnut plots rather than collectively are likely to reduce the contribution of resources/endowment in the yield gap. In addition, if more FHHs are involved in groundnut scaling activities (field trials/testing/demonstrations), then contribution of endowment/resources in the yield gap could be reduced significantly - the same findings by [42] when they studied the role of women participation in agricultural technology awareness activities on adoption and productivity of drought tolerant (DT) maize in Nigeria. Overall, our findings agree with [14] that agricultural productivity in Nigeria can be improved significantly through gender-sensitive policies and capacity building of female farmers.

Table 5. Decomposition details.

\begin{tabular}{cccc}
\hline Variable & Endowments & Coefficients & Interaction Term \\
\hline \multirow{2}{*}{ Adoption of improved varieties } & $0.0314^{* * *}$ & 0.113 & 0.042 \\
& $(0.0118)$ & $(0.101)$ & $(0.040)$ \\
\hline \multirow{2}{*}{ Groundnut plot tenure } & $-0.024^{*}$ & 0.056 & -0.013 \\
& $(0.014)$ & $(0.276)$ & $(0.063)$ \\
\hline \multirow{2}{*}{ Household involved in demos/trials } & $-0.016^{*}$ & 0.147 & 0.054 \\
Age of the household head & $(0.009)$ & $(0.127)$ & $(0.050)$ \\
& $-0.041^{* *}$ & 0.049 & -0.007 \\
Total male household members & $(0.018)$ & $(0.690)$ & $(0.097)$ \\
\hline \multirow{2}{*}{ Total female household members } & $0.038^{* * *}$ & 0.159 & -0.046 \\
& $(0.012)$ & $(0.343)$ & $(0.100)$ \\
\hline
\end{tabular}

${ }^{* * *} p<0.01,{ }^{* *} p<0.05,{ }^{*} p<0.1 ;$ values in parenthesis show standard errors.

\section{Summary and Conclusions}

The high levels of poverty among rural farming households in sub-Saharan Africa (SSA) have been associated with low agricultural productivity. Recent studies into this issue have linked a significant portion of this problem to pervasive gender yield gap in favor of MHHs compared to FHHs. Despite attempts by respective national governments and other development partners to address this problem, there still exists a persistent gender productivity gap in SSA's agricultural sector of not less than $20 \%$. Women farmers are disproportionately deprived of productive resources like land, labor, and other inputs even though they contribute more than $50 \%$ of the agricultural labor. This paper contributes to the existing literature on how this problem can be addressed by estimating and analyzing the groundnut gender yield gap among smallholder rural farmers in Nigeria. Using cross-sectional data collected from 1311 households, we estimate and analyze the groundnut gender yield using two complementary econometric models that allow building counterfactual outcomes to disentangle the impact of sex of the household head on the groundnut yield gap and analyzing specific policy options for closing the identified gap. We use the exogenous switching regression and Oaxaca-Blinder decomposition models to estimate and analyze the gender yield gap among smallholder groundnut farmers in Nigeria.

Consistent with findings from previous studies, we find a significant gender yield gap in favor of MHHs. From ESR, we find that with the same amount of resources like FHHs, MHHs will 
significantly lose their yield to the level that is as low as what FHHs are currently having. On the other hand, with the same amount of resources like MHHs, FHHs' yield will increase significantly but not to that level that MHHs are having. This implies that improving the endowments/resources and returns/coefficients of FHHs are critical in closing the gender yield gap. Similarly, using OB decomposition framework shows that MHHs had a significantly higher yield compared to FHHs and the difference in endowment/resources accounts for the largest and significant proportion of the yield gap. This could also be a confirmation of previous studies showing that women are just as efficient as men and their productivity could be equal if the amount of resources owned and managed by the two groups of households are similar. Further analysis of these significant endowment effects from the OB framework shows that adoption of improved groundnut varieties has an increasing effect on the gender yield gap through the endowments/resources. This implies that there is need for policy options that are targeted at boosting the productivity of improved groundnut varieties among FHHs. The OB decomposition results also points to the possibility of closing the gender yield gap by designing policy options aimed at making FHHs produce groundnut from their owned plots rather than collectively owned plots and involving more FHHs in groundnut scaling activities (field tests/trials/demonstrations) i.e., targeting FHHs will help in closing the groundnut gender yield gap. Therefore, availing improved groundnut varieties alone to female farmers is not enough in increasing their productivity unless this is accompanied by building their skills related to crop management practices.

Author Contributions: Conceptualization, C.O.; Formal analysis and writing, G.M.; review and editing, J.L., H.A. (Hippolyte Affognon), B.A., H.D., H.A. (Hakeem Ajeigbe), M.V., J.Y. and E.A. All authors have read and agreed to the published version of the manuscript.

Funding: This research was funded by Bill and Melinda Gates Foundation (BMGF) grant numbers OPP1114827 \& OPP1198373.

Acknowledgments: We gratefully acknowledge the financial support for this research by the Bill and Melinda Gates Foundation (BMGF).

Conflicts of Interest: The authors declare no conflict of interest.

\section{Appendix A}

Table A1. Determinants of groundnut yield (dependent variable: natural log of yield).

\begin{tabular}{cccccc}
\hline VARIABLES & $\begin{array}{c}\text { Model 1: } \\
\text { Traditional }\end{array}$ & $\begin{array}{c}\text { Model 2: } \\
\text { PSM }\end{array}$ & $\begin{array}{c}\text { Model 3: } \\
\text { Pooled ESR }\end{array}$ & $\begin{array}{c}\text { Model 4: } \\
\text { MHHs ESR }\end{array}$ & $\begin{array}{c}\text { Model 5: } \\
\text { FHHs ESR }\end{array}$ \\
\hline Sex of household head & $0.309^{* * *}$ & & & & \\
& $(0.0849)$ & & & & \\
Improved groundnut variety & $0.247^{* * *}$ & 0.0716 & $0.248^{* * *}$ & $0.206^{* * *}$ & $0.483^{* *}$ \\
& $(0.0465)$ & $(0.128)$ & $(0.0467)$ & $(0.0476)$ & $(0.242)$ \\
Natural log of plot size & $-0.364^{* * *}$ & 0.0382 & $-0.366^{* * *}$ & $-0.340^{* * *}$ & $-0.594^{* * *}$ \\
& $(0.0319)$ & $(0.0823)$ & $(0.0321)$ & $(0.0327)$ & $(0.183)$ \\
Planting on time & 0.0559 & $0.572^{* * *}$ & 0.0851 & 0.0485 & 0.285 \\
& $(0.0820)$ & $(0.190)$ & $(0.0819)$ & $(0.0859)$ & $(0.345)$ \\
Harvesting on time & 0.0793 & $0.416^{* *}$ & 0.0902 & 0.0443 & 0.0978 \\
& $(0.0773)$ & $(0.185)$ & $(0.0775)$ & $(0.0817)$ & $(0.375)$ \\
Individually owned plot & $0.112^{*}$ & $0.878^{* * *}$ & $0.149 * *$ & $0.126^{*}$ & 0.191 \\
& $(0.0634)$ & $(0.164)$ & $(0.0628)$ & $(0.0669)$ & $(0.317)$ \\
Plot intercropped & -0.0413 & $0.393^{* * *}$ & -0.0238 & -0.0462 & 0.220 \\
& $(0.0468)$ & $(0.133)$ & $(0.0468)$ & $(0.0475)$ & $(0.292)$ \\
Rotation on the plot & $0.110^{* *}$ & -0.168 & $0.106^{* *}$ & $0.155^{* * *}$ & $-0.502 *$ \\
& $(0.0497)$ & $(0.140)$ & $(0.0499)$ & $(0.0505)$ & $(0.294)$ \\
\hline
\end{tabular}


Table A1. Cont.

\begin{tabular}{|c|c|c|c|c|c|}
\hline VARIABLES & $\begin{array}{l}\text { Model 1: } \\
\text { Traditional }\end{array}$ & $\begin{array}{l}\text { Model 2: } \\
\text { PSM }\end{array}$ & $\begin{array}{l}\text { Model 3: } \\
\text { Pooled ESR }\end{array}$ & $\begin{array}{l}\text { Model 4: } \\
\text { MHHs ESR }\end{array}$ & $\begin{array}{l}\text { Model 5: } \\
\text { FHHs ESR }\end{array}$ \\
\hline \multirow[t]{2}{*}{ Poor soil fertility } & -0.143 & $0.875^{*}$ & -0.117 & -0.158 & 0.178 \\
\hline & $(0.148)$ & $(0.466)$ & $(0.148)$ & $(0.150)$ & $(0.815)$ \\
\hline \multirow[t]{2}{*}{ Average soil fertility } & 0.0500 & 0.129 & 0.0579 & 0.00727 & 0.216 \\
\hline & $(0.0801)$ & $(0.207)$ & $(0.0803)$ & $(0.0832)$ & $(0.322)$ \\
\hline \multirow[t]{2}{*}{ Good soil fertility } & $0.152^{* *}$ & 0.210 & $0.163^{* * *}$ & $0.131^{* *}$ & 0.261 \\
\hline & $(0.0627)$ & $(0.168)$ & $(0.0629)$ & $(0.0655)$ & $(0.259)$ \\
\hline \multirow[t]{2}{*}{ Natural log of seed rate } & $0.0648^{* * *}$ & -0.00261 & $0.0644^{* * *}$ & $0.0672 * * *$ & 0.0824 * \\
\hline & $(0.0108)$ & $(0.0221)$ & $(0.0108)$ & $(0.0115)$ & $(0.0426)$ \\
\hline \multirow[t]{2}{*}{ Fertilizer application rate } & $5.01 \times 10^{-6}$ & $-7.04 \times 10^{-6}$ & $2.83 \times 10^{-6}$ & $6.24 \times 10^{-6}$ & $5.66 \times 10^{-5}$ \\
\hline & $\left(1.68 \times 10^{-5}\right)$ & $\left(5.09 \times 10^{-5}\right)$ & $\left(1.69 \times 10^{-5}\right)$ & $\left(1.80 \times 10^{-5}\right)$ & $\left(5.72 \times 10^{-5}\right)$ \\
\hline \multirow[t]{2}{*}{ Manure application rate } & $-3.02 \times 10^{-6}$ & $1.63 \times 10^{-5}$ & $-1.64 \times 10^{-6}$ & $-6.52 \times 10^{-6}$ & 0.000126 \\
\hline & $\left(8.72 \times 10^{-6}\right)$ & $\left(2.91 \times 10^{-5}\right)$ & $\left(8.74 \times 10^{-6}\right)$ & $\left(8.67 \times 10^{-6}\right)$ & $\left(8.37 \times 10^{-5}\right)$ \\
\hline \multirow[t]{2}{*}{ Livestock grazing rate } & 0.00120 & $-0.00636^{* * *}$ & 0.000924 & 0.00140 & 0.00266 \\
\hline & $(0.000951)$ & $(0.00204)$ & $(0.000952)$ & $(0.000972)$ & $(0.00527)$ \\
\hline \multirow[t]{2}{*}{ Male labor rate } & 0.000158 & 0.000126 & 0.000171 & 0.000406 & -0.00142 \\
\hline & $(0.000509)$ & $(0.00117)$ & $(0.000511)$ & $(0.000535)$ & $(0.00178)$ \\
\hline \multirow[t]{2}{*}{ Female labor rate } & 0.000473 & 0.00204 & 0.000512 & 0.000333 & 0.00462 \\
\hline & $(0.000710)$ & $(0.00526)$ & $(0.000713)$ & $(0.000707)$ & $(0.0426)$ \\
\hline \multirow[t]{2}{*}{ Children labor rate } & 0.000343 & 0.0236 & 0.000379 & 0.000370 & 0.0678 \\
\hline & $(0.000728)$ & $(0.0218)$ & $(0.000730)$ & $(0.000716)$ & $(0.0431)$ \\
\hline \multirow[t]{2}{*}{ Striga control on plot } & -0.0962 & 0.0255 & -0.0980 & -0.0644 & -0.269 \\
\hline & $(0.0694)$ & $(0.181)$ & $(0.0696)$ & $(0.0714)$ & $(0.305)$ \\
\hline \multirow[t]{2}{*}{ Household head age } & $0.00630^{* *}$ & $0.0135^{* *}$ & $0.00677^{* * *}$ & $0.00631^{* *}$ & 0.00737 \\
\hline & $(0.00251)$ & $(0.00684)$ & $(0.00252)$ & $(0.00258)$ & $(0.0147)$ \\
\hline \multirow{2}{*}{$\begin{array}{l}\text { Household head years of } \\
\text { schooling }\end{array}$} & 0.00219 & $0.0498^{* * *}$ & 0.00292 & 0.00202 & -0.0381 \\
\hline & $(0.00318)$ & $(0.0150)$ & $(0.00319)$ & $(0.00318)$ & $(0.0284)$ \\
\hline \multirow{2}{*}{$\begin{array}{l}\text { Household head farming } \\
\text { main occupation }\end{array}$} & $-0.138^{* *}$ & 0.247 & $-0.135^{* *}$ & $-0.175^{* *}$ & 0.586 \\
\hline & $(0.0674)$ & $(0.186)$ & $(0.0676)$ & $(0.0692)$ & $(0.409)$ \\
\hline \multirow[t]{2}{*}{ Household head married } & 0.119 & $1.261^{* * *}$ & $0.222 *$ & 0.130 & 0.0441 \\
\hline & $(0.124)$ & $(0.219)$ & $(0.121)$ & $(0.160)$ & $(0.331)$ \\
\hline \multirow{2}{*}{$\begin{array}{l}\text { Household head years of } \\
\text { farming experience }\end{array}$} & 0.000516 & 0.00290 & 0.000627 & 0.000367 & 0.00917 \\
\hline & $(0.00227)$ & $(0.00687)$ & $(0.00227)$ & $(0.00229)$ & $(0.0137)$ \\
\hline \multirow{2}{*}{$\begin{array}{l}\text { Household head full time } \\
\text { farm labor }\end{array}$} & -0.0753 & 0.236 & -0.0644 & -0.0351 & $-0.630 * *$ \\
\hline & $(0.0633)$ & $(0.170)$ & $(0.0635)$ & $(0.0651)$ & $(0.313)$ \\
\hline \multirow{2}{*}{$\begin{array}{l}\text { Household head involved in } \\
\text { technology testing }\end{array}$} & $-0.104^{* *}$ & -0.168 & $-0.110 * *$ & $-0.120 * *$ & 0.294 \\
\hline & $(0.0511)$ & $(0.145)$ & $(0.0512)$ & $(0.0515)$ & $(0.354)$ \\
\hline \multirow{2}{*}{$\begin{array}{l}\text { Number of extension staff } \\
\text { visits }\end{array}$} & $-0.00808^{* * *}$ & $-0.0191 * * *$ & $-0.00837^{* * *}$ & $-0.00732 * *$ & -0.00624 \\
\hline & $(0.00296)$ & $(0.00719)$ & $(0.00297)$ & $(0.00308)$ & $(0.0182)$ \\
\hline \multirow{2}{*}{$\begin{array}{l}\text { Total male household } \\
\text { members }\end{array}$} & $-0.0223^{* * *}$ & 0.0353 & $-0.0216^{* * *}$ & $-0.0237^{* * *}$ & 0.00472 \\
\hline & $(0.00664)$ & $(0.0232)$ & $(0.00666)$ & $(0.00661)$ & $(0.0611)$ \\
\hline \multirow{2}{*}{$\begin{array}{l}\text { Total female household } \\
\text { members }\end{array}$} & $0.0208^{* * *}$ & -0.00468 & $0.0211^{* * *}$ & $0.0224^{* * *}$ & -0.0210 \\
\hline & $(0.00608)$ & $(0.0230)$ & $(0.00610)$ & $(0.00603)$ & $(0.0618)$ \\
\hline \multirow{2}{*}{$\begin{array}{l}\text { Member of household } \\
\text { trained in technology }\end{array}$} & $0.131 * *$ & -0.256 & $0.118^{* *}$ & 0.108 * & 0.216 \\
\hline & $(0.0576)$ & $(0.158)$ & $(0.0577)$ & $(0.0593)$ & $(0.356)$ \\
\hline \multirow{2}{*}{ Number of cultivated plots } & 0.0120 & $0.232 * * *$ & 0.0141 * & 0.0107 & 0.0245 \\
\hline & $(0.00738)$ & $(0.0484)$ & $(0.00739)$ & $(0.00733)$ & $(0.106)$ \\
\hline
\end{tabular}


Table A1. Cont.

\begin{tabular}{cccccc}
\hline VARIABLES & $\begin{array}{c}\text { Model 1: } \\
\text { Traditional }\end{array}$ & $\begin{array}{c}\text { Model 2: } \\
\text { PSM }\end{array}$ & $\begin{array}{c}\text { Model 3: } \\
\text { Pooled ESR }\end{array}$ & $\begin{array}{c}\text { Model 4: } \\
\text { MHHs ESR }\end{array}$ & $\begin{array}{c}\text { Model 5: } \\
\text { FHHs ESR }\end{array}$ \\
\hline Jigawa State & $-0.201^{* *}$ & $-0.688^{* * *}$ & $-0.227^{* * *}$ & $-0.234^{* * *}$ & -0.413 \\
& $(0.0833)$ & $(0.224)$ & $(0.0833)$ & $(0.0870)$ & $(0.448)$ \\
Kano State & 0.121 & $0.627^{* *}$ & 0.136 & 0.0774 & -0.442 \\
& $(0.0848)$ & $(0.285)$ & $(0.0850)$ & $(0.0866)$ & $(0.791)$ \\
Katsina State & 0.0302 & -0.143 & 0.0305 & -0.0293 & 0.415 \\
& $(0.0788)$ & $(0.213)$ & $(0.0791)$ & $(0.0815)$ & $(0.415)$ \\
Kebbi State & $0.897^{* * *}$ & $0.726^{* * *}$ & $0.923^{* * *}$ & $0.831^{* * *}$ & $1.190^{* *}$ \\
& $(0.0828)$ & $(0.251)$ & $(0.0828)$ & $(0.0852)$ & $(0.545)$ \\
Constant & $5.016^{* * *}$ & $-3.153^{* * *}$ & $5.074^{* * *}$ & $5.398^{* * *}$ & $4.092^{* * *}$ \\
& $(0.176)$ & $(0.428)$ & $(0.176)$ & $(0.212)$ & $(0.771)$ \\
\hline Observations & 1645 & 1645 & 1645 & 1513 & 132 \\
R-squared & 0.269 & 0.325 & 0.263 & 0.246 & 0.506 \\
\hline
\end{tabular}

Standard errors in parentheses: ${ }^{* * *} p<0.01,{ }^{* *} p<0.05,{ }^{*} p<0.1$.

Table A2. Propensity Score Matching (PSM) results.

\begin{tabular}{cc}
\hline Variables & Nearest Neighbor \\
\hline Male HH & 6.244 \\
Female HH & 5.720 \\
Difference & $0.524^{* * *}$ \\
Std. Error & 0.120 \\
t-stat & 4.360 \\
No. Obs. & \\
Male & 1513 \\
Female & 132 \\
\hline \multicolumn{2}{c}{$* * * p<0.01}$.
\end{tabular}

Table A3. Oaxaca-Blinder decomposition.

\begin{tabular}{|c|c|c|c|c|c|}
\hline VARIABLES & $\begin{array}{c}\text { Yield } \\
\text { Differential }\end{array}$ & $\begin{array}{c}\text { Yield } \\
\text { Decomposition }\end{array}$ & $\begin{array}{c}\text { Drivers of } \\
\text { Endowments }\end{array}$ & $\begin{array}{c}\text { Drivers of } \\
\text { Coefficients }\end{array}$ & $\begin{array}{l}\text { Drivers of } \\
\text { Interaction }\end{array}$ \\
\hline Improved groundnut variety & & & $\begin{array}{c}0.0314^{* * * *} \\
(0.0118)\end{array}$ & $\begin{array}{c}0.113 \\
(0.101)\end{array}$ & $\begin{array}{c}0.0421 \\
(0.0396)\end{array}$ \\
\hline Natural log of plot size & & & $\begin{array}{c}-0.000694 \\
(0.0227)\end{array}$ & $\begin{array}{l}-0.0622 \\
(0.0458)\end{array}$ & $\begin{array}{c}-0.000519 \\
(0.0170)\end{array}$ \\
\hline Planting on time & & & $\begin{array}{l}-0.00538 \\
(0.00966)\end{array}$ & $\begin{array}{c}0.218 \\
(0.327)\end{array}$ & $\begin{array}{l}-0.0261 \\
(0.0402)\end{array}$ \\
\hline Harvesting on time & & & $\begin{array}{l}-0.00497 \\
(0.00929)\end{array}$ & $\begin{array}{l}0.0485 \\
(0.348)\end{array}$ & $\begin{array}{c}-0.00599 \\
(0.0430)\end{array}$ \\
\hline Individually owned plot & & & $\begin{array}{c}-0.0244 \text { * } \\
(0.0141)\end{array}$ & $\begin{array}{l}0.0557 \\
(0.276)\end{array}$ & $\begin{array}{l}-0.0127 \\
(0.0630)\end{array}$ \\
\hline Plot intercropped & & & $\begin{array}{l}0.00997 \\
(0.0104)\end{array}$ & $\begin{array}{c}0.142 \\
(0.158)\end{array}$ & $\begin{array}{l}-0.0576 \\
(0.0649)\end{array}$ \\
\hline Rotation on the plot & & & $\begin{array}{l}-0.0112 \\
(0.00777)\end{array}$ & $\begin{array}{c}-0.296^{* *} \\
(0.135)\end{array}$ & $\begin{array}{c}0.0473 \\
(0.0362)\end{array}$ \\
\hline Poor soil fertility & & & $\begin{array}{c}0.00168 \\
(0.00241)\end{array}$ & $\begin{array}{l}0.00867 \\
(0.0214)\end{array}$ & $\begin{array}{l}-0.00357 \\
(0.00961)\end{array}$ \\
\hline Average soil fertility & & & $\begin{array}{l}0.000133 \\
(0.00154)\end{array}$ & $\begin{array}{c}0.0325 \\
(0.0520)\end{array}$ & $\begin{array}{c}0.00380 \\
(0.00940)\end{array}$ \\
\hline Good soil fertility & & & $\begin{array}{l}-0.0101 \\
(0.00771)\end{array}$ & $\begin{array}{l}0.0864 \\
(0.179)\end{array}$ & $\begin{array}{c}-0.00991 \\
(0.0213)\end{array}$ \\
\hline
\end{tabular}


Table A3. Cont.

\begin{tabular}{|c|c|c|c|c|c|}
\hline VARIABLES & $\begin{array}{c}\text { Yield } \\
\text { Differential }\end{array}$ & $\begin{array}{c}\text { Yield } \\
\text { Decomposition }\end{array}$ & $\begin{array}{c}\text { Drivers of } \\
\text { Endowments }\end{array}$ & $\begin{array}{c}\text { Drivers of } \\
\text { Coefficients }\end{array}$ & $\begin{array}{r}\text { Drivers of } \\
\text { Interaction }\end{array}$ \\
\hline Natural log of seed & & & $\begin{array}{l}-0.0180 \\
(0.0164)\end{array}$ & $\begin{array}{l}0.0423 \\
(0.123)\end{array}$ & $\begin{array}{l}-0.00407 \\
(0.0124)\end{array}$ \\
\hline Fertilizer rate & & & $\begin{array}{l}0.000434 \\
(0.00159)\end{array}$ & $\begin{array}{l}0.00867 \\
(0.0104)\end{array}$ & $\begin{array}{c}0.00350 \\
(0.00890)\end{array}$ \\
\hline Manure rate & & & $\begin{array}{c}0.00264 \\
(0.00360)\end{array}$ & $\begin{array}{c}0.0966 \\
(0.0619)\end{array}$ & $\begin{array}{l}-0.0536 \\
(0.0378)\end{array}$ \\
\hline Livestock plot grazing rate & & & $\begin{array}{c}0.00366 \\
(0.00378)\end{array}$ & $\begin{array}{l}0.00734 \\
(0.0314)\end{array}$ & $\begin{array}{l}0.00327 \\
(0.0142)\end{array}$ \\
\hline Male labor rate & & & $\begin{array}{l}-1.09 \times 10^{-5} \\
(0.00192)\end{array}$ & $\begin{array}{l}-0.0180 \\
(0.0185)\end{array}$ & $\begin{array}{l}4.88 \times 10^{-5} \\
(0.00862)\end{array}$ \\
\hline Female labor rate & & & $\begin{array}{c}-0.000450 \\
(0.00101)\end{array}$ & $\begin{array}{l}0.0116 \\
(0.115)\end{array}$ & $\begin{array}{c}-0.00579 \\
(0.0577)\end{array}$ \\
\hline Children labor rate & & & $\begin{array}{l}-0.000425 \\
(0.000881)\end{array}$ & $\begin{array}{c}0.160 \\
(0.117)\end{array}$ & $\begin{array}{l}-0.0773 \\
(0.0765)\end{array}$ \\
\hline Striga control on plot & & & $\begin{array}{l}-0.00161 \\
(0.00271)\end{array}$ & $\begin{array}{l}-0.0243 \\
(0.0373)\end{array}$ & $\begin{array}{c}-0.00510 \\
(0.0102)\end{array}$ \\
\hline Household head age & & & $\begin{array}{l}-0.0411^{* *} \\
(0.0180)\end{array}$ & $\begin{array}{l}0.0490 \\
(0.690)\end{array}$ & $\begin{array}{c}-0.00690 \\
(0.0972)\end{array}$ \\
\hline $\begin{array}{l}\text { Household head years of } \\
\text { schooling }\end{array}$ & & & $\begin{array}{l}-0.00294 \\
(0.00468)\end{array}$ & $\begin{array}{l}-0.128 \\
(0.0917)\end{array}$ & $\begin{array}{c}0.0582 \\
(0.0445)\end{array}$ \\
\hline $\begin{array}{l}\text { Household head farming } \\
\text { main occupation }\end{array}$ & & & $\begin{array}{c}0.00459 \\
(0.00607)\end{array}$ & $\begin{array}{l}0.660 * \\
(0.359)\end{array}$ & $\begin{array}{l}-0.0200 \\
(0.0275)\end{array}$ \\
\hline Household head married & & & $\begin{array}{l}-0.0240 \\
(0.0300)\end{array}$ & $\begin{array}{l}-0.0844 \\
(0.360)\end{array}$ & $\begin{array}{c}0.0159 \\
(0.0680)\end{array}$ \\
\hline $\begin{array}{l}\text { Household head years of } \\
\text { farming experience }\end{array}$ & & & $\begin{array}{c}-0.00255 \\
(0.0159)\end{array}$ & $\begin{array}{c}0.203 \\
(0.319)\end{array}$ & $\begin{array}{l}-0.0612 \\
(0.0967)\end{array}$ \\
\hline $\begin{array}{l}\text { Household head full time } \\
\text { farm labor }\end{array}$ & & & $\begin{array}{c}0.00434 \\
(0.00817)\end{array}$ & $\begin{array}{c}-0.484 * \\
(0.260)\end{array}$ & $\begin{array}{c}0.0735 \\
(0.0466)\end{array}$ \\
\hline $\begin{array}{l}\text { Household head involved in } \\
\text { technology testing }\end{array}$ & & & $\begin{array}{l}-0.0158 * \\
(0.00870)\end{array}$ & $\begin{array}{c}0.147 \\
(0.127)\end{array}$ & $\begin{array}{c}0.0544 \\
(0.0505)\end{array}$ \\
\hline $\begin{array}{c}\text { Number of extension staff } \\
\text { visits }\end{array}$ & & & $\begin{array}{c}0.00668 \\
(0.00656)\end{array}$ & $\begin{array}{l}0.00463 \\
(0.0794)\end{array}$ & $\begin{array}{c}-0.000980 \\
(0.0168)\end{array}$ \\
\hline $\begin{array}{l}\text { Total male household } \\
\text { members }\end{array}$ & & & $\begin{array}{c}0.0385^{* * *} \\
(0.0125)\end{array}$ & $\begin{array}{c}0.159 \\
(0.343)\end{array}$ & $\begin{array}{c}-0.0462 \\
(0.100)\end{array}$ \\
\hline $\begin{array}{l}\text { Total female household } \\
\text { members }\end{array}$ & & & $\begin{array}{c}-0.0352^{* * *} \\
(0.0114)\end{array}$ & $\begin{array}{l}-0.198 \\
(0.283)\end{array}$ & $\begin{array}{c}0.0681 \\
(0.0982)\end{array}$ \\
\hline $\begin{array}{l}\text { Member of household trained } \\
\text { in technology }\end{array}$ & & & 0.0140 & 0.0212 & 0.0140 \\
\hline Number of cultivated plots & & & $\begin{array}{l}-0.0131 \\
(0.00909)\end{array}$ & $\begin{array}{l}0.0412 \\
(0.320)\end{array}$ & $\begin{array}{c}-0.0167 \\
(0.130)\end{array}$ \\
\hline Jigawa State & & & $\begin{array}{l}-0.0429 * * \\
(0.0190)\end{array}$ & $\begin{array}{c}-0.0404 \\
(0.103)\end{array}$ & $\begin{array}{l}-0.0327 \\
(0.0839)\end{array}$ \\
\hline Kano State & & & $\begin{array}{l}-0.0122 \\
(0.0137)\end{array}$ & $\begin{array}{l}-0.102 \\
(0.156)\end{array}$ & $\begin{array}{l}0.0820 \\
(0.126)\end{array}$ \\
\hline Katsina State & & & $\begin{array}{l}0.000617 \\
(0.00198)\end{array}$ & $\begin{array}{c}0.0834 \\
(0.0796)\end{array}$ & $\begin{array}{c}-0.00934 \\
(0.0176)\end{array}$ \\
\hline Kebbi State & & & $\begin{array}{l}-0.109 * * * \\
(0.0239)\end{array}$ & $\begin{array}{l}0.0746 \\
(0.115)\end{array}$ & $\begin{array}{l}-0.0474 \\
(0.0733)\end{array}$ \\
\hline Total & & & $\begin{array}{l}-0.258^{* * *} \\
(0.0594)\end{array}$ & $\begin{array}{l}-0.270 \\
(0.263)\end{array}$ & $\begin{array}{c}-0.0375 \\
(0.256)\end{array}$ \\
\hline
\end{tabular}


Table A3. Cont.

\begin{tabular}{|c|c|c|c|c|c|}
\hline VARIABLES & $\begin{array}{c}\text { Yield } \\
\text { Differential }\end{array}$ & $\begin{array}{c}\text { Yield } \\
\text { Decomposition }\end{array}$ & $\begin{array}{c}\text { Drivers of } \\
\text { Endowments }\end{array}$ & $\begin{array}{l}\text { Drivers of } \\
\text { Coefficients }\end{array}$ & $\begin{array}{l}\text { Drivers of } \\
\text { Interaction }\end{array}$ \\
\hline Prediction_1 & $\begin{array}{c}5.679 * * * \\
(0.112)\end{array}$ & & & & \\
\hline Prediction_2 & $\begin{array}{l}6.244^{* * *} \\
(0.0243)\end{array}$ & & & & \\
\hline Difference & $\begin{array}{c}-0.565^{* * *} \\
(0.114)\end{array}$ & & & & \\
\hline Endowments & & $\begin{array}{c}-0.258^{* * *} \\
(0.0594)\end{array}$ & & & \\
\hline Coefficients & & $\begin{array}{l}-0.270 \\
(0.263)\end{array}$ & & & \\
\hline Interaction & & $\begin{array}{c}-0.0375 \\
(0.256)\end{array}$ & & & \\
\hline Constant & & & & $\begin{array}{l}-1.307 \\
(0.800)\end{array}$ & \\
\hline Observations & 1645 & 1645 & 1645 & 1645 & 1645 \\
\hline
\end{tabular}

Standard errors in parentheses: ${ }^{* * *} p<0.01,{ }^{* *} p<0.05,{ }^{*} p<0.1$.

\section{References}

1. World Bank. Poverty and Shared Prosperity 2018: Piecing Together the Poverty Puzzle; World Bank: Washington, DC, USA, 2018; License: Creative Commons Attribution CC BY 3.0 IGO.

2. Zadawa, A.N.; Omran, A. Rural development in Africa: Challenges and opportunities. In Sustaining Our Evironment for Better Future; Omran, A., Schwarz-Herion, O., Eds.; Springer: Singapore, 2020.

3. Odusola, A. Fiscal Space, Poverty and Inequality in Africa. Afr. Dev. Rev. 2017, 29, 1-14. [CrossRef]

4. Fan, S.; Johnson, M.; Saurkar, A.; Makombe, T. Investing in African Agriculture to Halve Poverty by 2015. IFPRI Discussion Paper 00751. Development Strategy and Governance Division, 2008. Available online: https://www.fanrpan.org/archive/documents/d00484/Agric_poverty_IFPRI_Feb2008.pdf (accessed on 4 July 2020).

5. Ligon, E.; Sadoulet, E. Estimating the Effects of Aggregate Agricultural Growth on the Distribution of Expenditure; Background paper for the World Development Report, 2008; The World Bank: Wasington, DC, USA, 2008.

6. Mugisha, J.; Diiro, G. Explaining the Adoption of Imoproved Maize Varieties and its Effects on Yields among Smallholder Maize Farmers in Eastern and Central Uganda. Middle East J. Sci. Res. 2010, 5, 6-13.

7. Shimeles, A.; Verdier-Chouchane, A.; Boly, A. Introduction: Understanding the Challenge of the Agricultural Sector in Sub-Saharan Africa. In Building a Resilient and Sustainable Agriculture in Sub Saharan Africa; Shimeles, A., Verdier-Chouchane, A., Boly, A., Eds.; Palgrave Macmillan: Cham, Switzerland, 2018.

8. Christiaensen, L.; Demery, L.; Kuhl, J. The (evolving) role of agriculture in poverty reduction-An empirical perspective. J. Dev. Econ. 2011, 96, 239-254. [CrossRef]

9. Slavchevska, V. Gender differences in agricultural productivity: The case of Tanzania. Agric. Econ. 2015, 46, 335-355. [CrossRef]

10. Karamba, R.W.; Winters, P.C. Gender and agricultural productivity: Implications of the Farm Input Subsidy Program in Malawi. Agric. Econ. 2015, 46, 357-374. [CrossRef]

11. Oseni, G.; Corral, P.; Goldstein, M.; Winters, P. Explaining gender differentials in agricultural production in Nigeria. Agric. Econ. 2015, 46, 285-310. [CrossRef]

12. Mukasa, A.N.; Salami, A.O. Sources of gender productivity differentials in Africa: A cross-country Comparison. African Development Bank. Afr. Econ. Brief 2016, 4.

13. Ali, D.; Bowen, D.; Deininger, K.; Duponchel, M. Investigating the Gender Gap in Agricultural Productivity: Evidence from Uganda. World Dev. 2016, 87, 152-170. [CrossRef]

14. Rufai, A.; Salman, K.; Salawu, M. Input Utilization and Agricultural Labour Productivity: A Gender Analysis. In Building a Resilient and Sustainable Agriculture in Sub Saharan Africa; Shimeles, A., Verdier-Chouchane, A., Boly, A., Eds.; Palgrave Macmillan: Cham, Switzerland, 2018.

15. FAO. The State of Food and Agriculture: Women in Agriculture, Closing the Gender Gap for Development; FAO: Rome, Italy, 2011. 
16. Kilic, T.; Palacios-López, A.; Goldstein, M. Caught in a Productivity Trap: A Distributional Perspective on Gender Differences in Malawian Agriculture. World Dev. 2015, 70, 416-463. [CrossRef]

17. Levin, C.; Ruel, M.T.; Morris, S.S.; Maxwell, D.G.; Armar-Klemesu, M.; Ahiadeke, C. Working Women in an Urban Setting: Traders, Vendors and Food Security in Accra. World Dev. 1999, 27, 1977-1991. [CrossRef]

18. Elijah, O.; Okoruwa, V.; Ajani, O. Analysis of differences in Rural-Urban Households Food Expenditure Share in Kwara and Kogi States of Nigeria. Glob. J. Agric. Sci. 2011, 10, 1-18.

19. Dodson, B.; Chiweza, A.; Riley, L. Gender and Food Insecurity in Southern Africa Cities. Available online: https://www.alnap.org/system/files/content/resource/files/main/afsun10.pdf (accessed on 24 August 2020).

20. Gebre, G.G.; Isoda, H.; Rahut, D.B.; Amekawa, Y.; Nomura, H. Gender differences in agricultural productivity: Evidence from maize farm households in southern Ethiopia. GeoJournal 2019. [CrossRef]

21. Martey, E.; Prince, M.; Etwire, P.M.; Adogoba, D.; Tengey, T.; Boukar, O. Ousmane Gender Gaps in Adoption, Production and Preferences for Cowpea attributes in Northern Ghana. Final Report. CSIR-SARI 2019; Soybean Innovation Lab, University of Illinois at Urbana-Champaign: Urbana, IL, USA, 2019.

22. Mugisha, J.; Sebatta, C.; Mausch, K.; Ahikiriza, E.; Okello, D.K.; Njuguna, E.M. Bridging the gap: Decomposing sources of gender yield gaps in Uganda groundnut production. Gender Technol. Dev. 2019, 23, 19-35. [CrossRef] [PubMed]

23. Schultz, T.P. Women's role in Agricultural Household bargaining and human capital investments. In Agricultural and Resource Economics Handbook; Gardener, B., Rausser, G., Eds.; Elsevier: Amsterdam, The Netherlands, 2001; pp. 383-456.

24. Peterman, A.; Quisumbing, A.; Behrman, J.; Nkonya, E. Understanding the Complexities Surrounding Gender Differences in Agricultural Productivity in Nigeria and Uganda. J. Dev. Stud. 2011, 47, 1482-1509. [CrossRef]

25. Palacios-López, A.; López, R. The Gender Gap in Agricultural Productivity: The Role of Market Imperfections. J. Dev. Stud. 2015, 51, 1175-1192. [CrossRef]

26. Kassie, M.; Ndiritu, S.W.; Stage, J. What Determines Gender Inequality in Household Food Security in Kenya? Application of Exogenous Switching Treatment Regression. World Dev. 2014, 56, 153-171. [CrossRef]

27. Miguel, E.; Satyanath, S.; Sergenti, E. Economic Shocks and Civil Conflict: An Instrumental Variables Approach. J. Political Econ. 2004, 112, 725-753. [CrossRef]

28. Lokshin, M.; Sajaia, Z. Maximum Likelihood Estimation of Endogenous Switching Regression Models. Stata J. 2004, 4, 282-289. [CrossRef]

29. Araar, A. The Treatment Effect: Comparing the ESR and PSM Methods with an Artificial Example. 2015. Available online: http://dasp.ecn.ulaval.ca/temp/Annex_ESR_Average_Treatment_Araar.pdf (accessed on 18 April 2019).

30. Di Falco, S.; Veronesi, M.; Yesuf, M. Does Adaptation to Climate Change Provide Food Security? A Micro-Perspective from Ethiopia. Am. J. Agric. Econ. 2011, 93, 829-846. [CrossRef]

31. Bidzakin, J.K.; Fialor, S.C.; Awunyo-Vitor, D.; Yahaya, I.; Aye, G. Impact of contract farming on rice farm performance: Endogenous switching regression. Cogent Econ. Finance 2019, 7, 1618229. [CrossRef]

32. Carter, D.W.; Milon, J.W. Price Knowledge in Household Demand for Utility Services. Land Econ. 2005, 81, 265-283. [CrossRef]

33. Oaxacca, R. Male-Female wage differentials in urban labour markets. Int. Econ. Rev. 1973, 14, 693-709. [CrossRef]

34. Blinder, A.S. Wage Discrimination: Reduced Form and Structural Estimates. J. Hum. Resour. 1973, 8, 436. [CrossRef]

35. Jann, B. The Blinder-Oaxacca decomposition for linear regression. Stata J. 2008, 8, 453-479. [CrossRef]

36. Vabi, M.B.; Sadiq, A.S.; Mustapha, A.; Suleiman, A.; Affognon, H.; Ajeigbe, H.A.; Kasim, A.A. Patterns and drivers of the adoption of improved groundnut technologies in North-western Nigeria. Afr. J. Agric. 2019, 6, 1-16. Available online: www.internationalscholarsjournal.org (accessed on 24 August 2020).

37. Zuza, E.; Muitia, A.; Amane, M.; Brandenburg, R.; Mondjanam, A. Effect of Harvesting time on groundnut Yield and Yield Components in Northern Tanzania. J. Postharvest Technol. 2017, 5, 55-63.

38. Aryal, J.P.; Mottaleb, K.A.; Rahut, D.B. Untangling gender differentiated food security gaps in Bhutan: An application of exogenous switching treatment regression. Rev. Dev. Econ. 2018, 23, 782-802. [CrossRef] 
39. Paudel, G.P.; Gartaula, H.; Rahut, D.B.; Craufurd, P.Q. Gender differentiated small-scale farm mechanization in Nepal hills: An application of exogenous switching treatment regression. Technol. Soc. 2020, 61, 101250. [CrossRef] [PubMed]

40. Quisumbing, A.R. Male-female differences in agricultural productivity: Methodological issues and empirical evidence. World Dev. 1996, 24, 1579-1595. [CrossRef]

41. Aguilar, A.; Carranza, E.; Goldstein, M.; Kilic, T.; Oseni, G. Decomposition of gender differentials in agricultural productivity in Ethiopia. Agric. Econ. 2015, 46, 311-334. [CrossRef]

42. Ayinde, O.; Abdoulaye, T.; Olaoye, G.; Oloyede, A. Evaluation of Women's On-Farm Trial of SDrought Tolerant Maize in Southern Guinea Savannah Agro-Ecological Zone of Nigeria. In Building a Resilient and Sustainable Agriculture in Sub Saharan Africa; Shimeles, A., Verdier-Chouchane, A., Boly, A., Eds.; Palgrave Macmillan: Cham, Switzerland, 2018.

Publisher's Note: MDPI stays neutral with regard to jurisdictional claims in published maps and institutional affiliations.

(C) 2020 by the authors. Licensee MDPI, Basel, Switzerland. This article is an open access article distributed under the terms and conditions of the Creative Commons Attribution (CC BY) license (http://creativecommons.org/licenses/by/4.0/). 